\title{
PRKCD Gene
}

National Cancer Institute

\section{Source}

National Cancer Institute. PRKCD Gene. NCI Thesaurus. Code C150118.

This gene plays a role in the regulation of both cell death and cell survival. 